\title{
Correction to: Association between hospital and ICU structural factors and patient outcomes in China: a secondary analysis of the National Clinical Improvement System Data in 2019
}

\author{
Zhen $\mathrm{Li}^{1+}{ }^{1}$, Xudong Ma ${ }^{2 \dagger}$, Sifa Gao ${ }^{2 \dagger}$, Qi Li ${ }^{1}$, Hongbo Luo ${ }^{1}$, Jianhua Sun ${ }^{1}$, Wei Du' ${ }^{1}$, Longxiang Su', Lu Wang ${ }^{1}$, \\ Qing Zhang ${ }^{1}$, Zunzhu Li ${ }^{1 *}$, Xiang Zhou ${ }^{1 *}$ and Dawei Liu ${ }^{1 *}$ on behalf of China National Critical Care Quality \\ Control Center Group
}

\section{Correction to: Critical Care (2022) 26:24 \\ https://doi.org/10.1186/s13054-022-03892-7}

Following publication of the original article [1], the authors identified an error in the corresponding authors. The author Zhen Li is first author not a corresponding author.

The author group has been updated above and the original article [1] has been corrected.

\section{Author details}

${ }^{1}$ Department of Critical Care Medicine, Peking Union Medical College Hospital, Chinese Academy of Medical Sciences, Beijing 100730, China. ${ }^{2}$ Department of Medical Administration, National Health Commission of the People's Republic of China, Beijing 100044, China.

Published online: 11 February 2022
Reference

1. Li Z, et al. Association between hospital and ICU structural factors and patient outcomes in China: a secondary analysis of the National Clinical Improvement System Data in 2019. Criti Care. 2022;26:24. https://doi.org/ 10.1186/s13054-022-03892-7.

\section{Publisher's Note}

Springer Nature remains neutral with regard to jurisdictional claims in published maps and institutional affiliations.

*Correspondence: 18612671363@163.com;zx_pumc@163.com; dwliu98@163.com

${ }^{\dagger}$ Zhen Li, Xudong Ma and Sifa Gao contributed equally to this work ${ }^{1}$ Department of Critical Care Medicine, Peking Union Medical College Hospital, Chinese Academy of Medical Sciences, Beijing 100730, China

Full list of author information is available at the end of the article permits use, sharing, adaptation, distribution and reproduction in any medium or format, as long as you give appropriate credit to the original author(s) and the source, provide a link to the Creative Commons licence, and indicate if changes were made. The images or other third party material in this article are included in the article's Creative Commons licence, unless indicated otherwise in a credit line to the material. If material is not included in the article's Creative Commons licence and your intended use is not permitted by statutory regulation or exceeds the permitted use, you will need to obtain permission directly from the copyright holder. To view a copy of this licence, visit http://creativecommons.org/licenses/by/4.0/. The Creative Commons Public Domain Dedication waiver (http://creativecommons.org/publicdomain/zero/1.0/) applies to the data made available in this article, unless otherwise stated in a credit line to the data. 